10. Случик І.Й. Біоіндикація стану довкілля на урбанізованій території за допомогою представників роду Populus L.: автореф. дис. ... канд. біол. наук: 03.00.16. Чернівці, 2000. 20 с.

11. Стольберг Ф.В. Экология города: Учебник. К.: Либра, 2000. 464 c.

12. Тополиный пух как самый теплый и экологичный наполнитель. URL: https://rodovid.me/soznatelnoe_potreblenie/topolinyy-puh-kak-samyyteplyy-i-ekologichnyy-napolnitel.html. (дата звернення 10.05.2021)

13. Ishchuk L.P., Krupa N.M., Priadkina G.O. Characterization of pigment apparatus in leaves of Salicaceae Mirbel species. Ukrainian Journal of Ecology. 2018. № 8 (1). P. 426-431. doi: 10.15421/2018_231

DOI https://doi.org/10.30525/978-9934-26-111-4-28

\title{
INFLUENCE OF ALIMENTARY XENOESTROGENS ON CHOLINERGIC REGULATION IN DIFFERENT AGE ANIMALS
}

\author{
Lykholat O. A. \\ Doctor of Biological Sciences, Professor, \\ Professor at the Department of Hotel and Restaurant Business \\ and Commodity Science \\ University of Custom and Finance
}

Lykholat T. Yu. PhD, Docent at the Department of Microbiology, Virologists and Biotechnology Oles Honchar Dnipro National University

Kravchuk K. V. Master at the Department of Physiology and Introduction of Plants Oles Honchar Dnipro National University Dnipro, Ukraine

In modern industrial animal husbandry, poultry farming and fish farming with intensive animal husbandry technologies, technological regulations are violated, during which hormonal growth stimulants harmful to human health are often illegally used to significantly increase productivity in animal husbandry. Products containing veterinary drugs are extremely dangerous to 
human health because hormonal growth stimulants - stilbenes (steroid hormones) have carcinogenic activity and cause impaired puberty and reproductive ability. Hormones do not completely destroyed during heat treatment of products. Therefore, all the hormones that are initially present in meat, milk, eggs, vegetables and fruits, remain there, although sometimes in smaller doses. Steroid hormones are destroyed during heat treatment the least. Male and female hormones are found in meat - beef, pork, chicken, only female - in milk and eggs, phytohormones - in vegetables and fruits, the most popular is phytoestrogen, which is contained in soy. Animal sex hormones are identical to human hormones. All hormones used in animal husbandry can affect the human body. Once in the human body with food, hormones are perceived by them as their own $[1,2]$. Food is one of the main routes of estrogen exposure to humans from the environment.

Many pesticides have estrogen-like properties and the risk of consuming contaminated products is quite high. There is a threat of pesticide residues in baby food, despite the strict legislation of the European Union (EU) on the need to ensure the security of their supply given the low levels of residual pesticide content [3].

Bisphenol A (BPA) is used in the production of polycarbonate plastics, epoxy resins, food packaging and coatings, dental sealants, rubber chemicals and flame retardants. Exposure to BPA occurs through inhalation of air, consumption of food and drinking water and directly through products containing this compound [4]. The effects of BPA can be harmful to humans, especially in terms of behavioral and other effects in children [5].

Neurotoxicity is one of the most serious toxicological problems, as damage to even a small number of neurons can have unpredictable consequences for the whole body. One of the most important aspects of the integral functioning of the organism is the presence of molecular mechanisms of connection of signaling systems, which ensure the realization of physiological and biochemical effects of hormones and neurotransmitters. The blood-brain barrier is a structure that functions through close contact between endothelial and adjacent neuroglial cells. Violation of neuroendocrine homeostasis in the endocrine system by chemicals can lead to a number of shifts [6].

Due to the risk of contamination of the diet of prepubertal children as a particularly sensitive population with chemicals with endocrine properties, it is necessary to analyze the risks of further health disorders.

To simulate the effects of exogenous estrogen in vivo, rat food was treated with Sinestrol (meso-3,4-di- (para-oxyphenyl) -hexane), a derivative of stilbene that differs chemically from steroidal estrogenic hormones (female sex hormones) but biological and therapeutic properties close to 
them - at the rate of $2 \mu \mathrm{g} / \mathrm{kg}$ body weight for 45 days. At the beginning of the experiment, the age of the experimental animals was 3 months -in the prepubertal period (group II, $\mathrm{n}=6$ ) and 6 months - mature (group IV, $\mathrm{n}=6$ ). Control groups consisted of intact animals of appropriate age (groups I, $\mathrm{n}=6$ and III, $\mathrm{n}=6$ ).

The studies were carried out in accordance with the requirements of Directive № 2010/63 / EC on the protection of animals used for scientific purposes [7].

In an in vitro model, Sinestrol was added to the test samples at a concentration of $0.5 \mathrm{nmol} / \mathrm{l}$, followed by incubation for 1 hour. An appropriate aliquot of saline was added to the control samples.

Evaluation of cholinergic regulation was carried out by the activity of acetylcholinesterase (AChE), as enzyme responsible for the hydrolysis of acetylcholine at cholinergic synapses.

Statistical data processing was performed using the application package Statistica 6.0 (StatSoft, USA). The difference between the comparative values was considered probable at $\mathrm{p}<0.05$.

In the study of $\mathrm{AChE}$ in the brain it was shown that in younger experimental rats its activity is higher by $22 \%$ compared to control indicators. In the older group, in experimental females enzyme activation by $15 \%$ was observed. When comparing the enzyme activity of 3-month-old and 6-month-old animals, there was a tendency to increase it.

Inhibition of enzyme activity was determined in blood serum and liver tissue: in animals during puberty, the indicators were significantly different from those of the corresponding control. For mature females, deviations in activity should be less pronounced. Decreased activity of AChE in blood serum and liver may be due to deterioration of the synthesizing function of the liver, in particular congestion in the liver (due to impaired hemodynamics) and kidneys.

The study of the effect of synthetic estrogens on the activity of AChE in in vitro experiments did not reveal probable changes in all studied tissues of animals of both experimental groups.

Thus, with alimentary exposure to estrogen, acetylcholinesterase activity in blood serum and liver tissue was lower in females during puberty than in adult rats, indicating a lower efficiency of mediator transmission in the corresponding cholinergic neurons of younger rats. When AChE is inhibited, acetylcholine is released very slowly from the receptors (by diffusion), which leads to disruption of nerve impulse transmission. This can cause serious disorders in the body vital activity.

Preservation of activating effects at the level of the cerebral cortex proves the stability of this department: the activation of the enzyme in the 
cerebral cortex is evidence of high functional plasticity of brain tissue. At the same time, the stress in the cholinergic mediator system was higher in younger rats. Deterministic stress in the cholinergic mediator system of the brain against the background of inhibition of ACE in blood serum and liver tissue with a predominance in females during puberty.

Given that the actions of estrogen affect the entire central nervous system and include signaling pathways that intersect with other mediators, such as neurotransmitters and neuromodulators, as consequence, affecting the processes associated with autonomic regulation, neuroprotection, etc [8]. Such phenomena can further trigger the reduction of the potential of compensatory mechanisms, including adaptation and apoptosis, affect the regulation of brain homeostasis, as well as directly affect intracellular processes during cell development and differentiation, resulting in adverse health problems.

Females in the prepubertal period were more susceptible than adult animals to dietary synthetic estrogens, arguing that age is another factor in xenoestrogen exposure. Due to changes in the rate of reactions of the detoxification path, rather than in the metabolism of estrogen entering the body, in particular with food, animals became less sensitive to the effects of these substances with age.

It is obvious that in vitro the antioxidant phenolic structure of estrogen phenols dominates, while after their in vivo administration, age- and dosedependent biotransformation occurs, with subsequent prooxidant effects in addition to antioxidant structures. The effects are higher in females at puberty compared to adult rats, both in vitro and in vivo, indicating the existence of specific age-related physiological conditions that determine high sensitivity to exogenous estrogen-like compounds.

\section{References:}

1. Papaioannou M.D., Koufaris C., Gooderham N.J. The cooked meatderived mammary carcinogen 2-amino-1-methyl-6-phenylimidazo[4,5b]pyridine (PhIP) elicits estrogenic-like microRNA responses in breast cancer cells. Toxicol. Lett. 2014. Vol. 17; 229. № 1. P. 9-16.

2. Lykholat T.Y., Alexeyeva A.A., Holubiev M.I., Lykholat O.A., Marenkov O.M. Influence of substances destroying the endocrine system on the state of fauna representatives. Effects of pollution and climate change on the ecosystem components: Monograph. Edited by Y. V. Lykholat. Praha, 2021. P. 136-159.

3. Hercegová A., Dömötörová M., Matisová E.Sample preparation methods in the analysis of pesticide residues in baby food with subsequent 
chromatographic determination. J. Chromatogr. A. 2007. Vol. 15, 1153, № 1-2. P. 54-73.

4. Fenichel P., Chevalier N., Brucker-Davis F. Bisphenol A: an endocrine and metabolic disruptor. Ann. Endocrinol. 2013. Vol. 74. № 3. P. 211-220.

5. Rochester J.R. Bisphenol A and human health: a review of the literature. Reprod. Toxicol. 2013. Vol. 42. P. 132-155.

6. De Coster S., van Larebeke N. Endocrine-disrupting chemicals: associated disorders and mechanisms of action. J. Environ. Public. Health. 2012. Vol. 2012. P. 696-713.

7. Council Directive 2010/63/EU of 22 September 2010 on the protection of animals used for scientific purposes. Official Journal of the European Communities. 2010. L. 276. P. 33-79.

8. McEwen B.S., Akama K.T., Spencer-Segal J.L., Arpino G. Estrogen effects on the brain: actions beyond the hypothalamus via novel mechanisms. Behav Neurosci. 2012. Vol. 126. № 1. P. 4-16.

DOI https://doi.org/10.30525/978-9934-26-111-4-29

\title{
ТРАНСМІСІЙНА ЕЛЕКТРОННА МІКРОСКОПІЯ В МЕДИЦИНІ ТА ЇЇ ПЕРСПЕКТИВИ
}

\author{
Харчук М. С. \\ кандидат біологічних наук,
} науковий співробітник лабораторії біологічних полімерних сполук,

Інститут мікробіології і вірусології імені Д. К. Заболотного

Начіональної академії наук Украӥни, асистент кафедри біології

Національний медичний університет імені О. О. Богомольия

\section{Гурняк О. М.}

кандидат біологічних наук, старший викладач кафедри біології

Національний медичний університет імені О. О. Богомольия м. Київ, Украӥна

Мікроскопічні методи $\epsilon$ методологічним підгрунтям наукових досліджень в галузях біології та прикладної медицини. Світлова мікроскопія (CM) у медико-біологічних дослідженнях у порівнянні 